\title{
Education for Sustainability
}

\author{
Learning from and with living systems
}

\author{
CAROLINE MCCAW
}

\begin{abstract}
This paper proposes an approach to teaching and learning that reflects the idea that to undergo systemic change we need to learn from and with living systems. I reflect on two projects that illustrate small steps towards this emergent practice and draw upon theories that may help to frame this ecological approach. Drawing these frameworks and design education projects together helps to understand education for sustainability as embedded in productive learning relationships, involving thinking reflectively on our messages and actions. According to the UNESCO Policy Brief (2018) Education is a crucial element of a sustainable development agenda and needs to be holistic and transformational. These practices of taking education outside of the classroom are illustrated through examples of project-based learning in a Communication Design degree at Otago Polytechnic in Dunedin New Zealand in partnership with local environmental groups, and aim to be both holistic and potentially transformative. Examining the projects in this way helps to see the requirement for empathy including and beyond human-centred design, an understanding of the systems in which the student projects sit, and acknowledging te Ao Māori, an indigenous worldview unique to New Zealand.
\end{abstract}

KEYWORDS: Project Based Learning; More-than-human; Sustainability Education

This paper considers emerging teaching and learning practices where design students are taken outside of their classrooms, to work with living systems, and to develop project responses with more-than-human beings. I will first outline three frameworks for thinking around ecological and systems approaches, then describe two communication design student projects and consider how they may be examples of these approaches. Reflecting on some contemporary theories and practices I will consider some key insights and questions for educators to consider.

In my own teaching practice within a Design School context, I focus on project-based learning, most often with social and environmental community groups as 'clients'. I find there are many learning opportunities for senior students engaged with 'outside' professionals and their 'real-world problems'. Along with their design-focused learning outcomes, students report gaining valuable experience working with people outside the classroom. They learn about themselves as active citizens, and learn about social and environmental issues they may not have considered, through perspectives other than their own. In this paper I will outline a subset of this approach to teaching and learning through student projects that consider the needs 
of places and beings that are more, or other-than-human - relationships sought through engaging with local environments. I will outline how our design experiences led to design prototypes, thinking tools, or ways for both students and partners to communicate sites, experiences and opportunities with each other and with others, towards thinking beyond human perspectives.

\section{Frameworks}

Here are three frameworks I find useful for considering these projects:

1. Ecological Systems and the more-than-human. Ecology is by definition, a relatively recent, transdisciplinary science focused on the relationship between living organisms and their environments first conceived in the early $20^{\text {th }}$ century. ${ }^{1}$ Ecologies and ecosystems are terms now more broadly used by writers from a wide range of disciplines, from humanities to project management, to refer to complex adaptive systems thinking. While some argue that the term has become too generalized to be useful, I hope to focus here on the idea of natural ecologies as dynamic and open-ended systems in which we are always a part. David Abram, an American ecologist and philosopher first used the term "more-than-human" as a way of referring to those elements that are "earthly" (1996) although the term has since been adopted by many other scholars, within a broader ecological approach. Abram also talks about "a commonwealth of breath" (2019), a living systems approach that draws upon indigenous knowledge, to counteract the abstraction of climate change debate. As an educator I believe we can learn a wide range of disciplinary and more-than-disciplinary ideas and tools through active engagement in these systems.

2. Systems thinking. Although most regularly used to solve identified problems, systems thinking is a useful framework that allows us to consider inter-related and larger systems, including ecological ones, in which we are part. "Systems thinking in practice encourages us to explore inter-relationships (context and connections), perspectives (each actor has their own unique perception of the situation) and boundaries (agreeing on scope, scale and what might constitute an improvement)." (Allen, n.d. https://learningforsustainability.net/systems-thinking/) According to the UNESCO Policy Brief (2018, Education for Sustainable Development and the SDGs) Education is a crucial element of a sustainable development agenda and needs to be holistic and transformational.

Through taking education outside of the classroom, and considering the systems that we live within, we work holistically and in partnership with local environmental groups. Students aspire to work in ways that are potentially transformative, and may be transformed in the process.

3. Te Ao Māori. A third framework for thinking through practices based in the natural world is through te Ao Māori, indigenous epistemologies specific to Aotearoa New Zealand. When we consider our natural world - and the islands that we live on as places shared between settlers and indigenous Māori people - it is through a bi-cultural lens.

1 "A relatively new science, its modern roots emerged in the early 20th century with the work of Frederic Clements and Henry Gleason, American botanists who studied the interactions between plant communities, and Sir Arthur Tansley, a British botanist and zoologist whose research on the interactions between plant and animal communities and the environment led him to coin the term "ecosystem" in 1935 (Reed and Lister, 2014) 
The Environment Guide website (www.environmentguide.org.nz) published by the Environment Foundation and supported by the New Zealand Law Foundation outlines legislation relating to land use, and describes te Ao Māori (as Māori worldview) this way:

"The Māori worldview considers everything living and non-living to be interconnected. Whakapapa describe these connections and tell the story of how people, the landscape, plants and animals came into being. People, plants and animals are all descendants of Ranginui (the sky father) and Papatuanuku (the earth mother) and their children, which means humans are therefore, intrinsically linked with biodiversity. The concepts of mauri (life force), mana (authority/power), tapu (sacred and restricted customs) and wairua (spirit) are important to consider in relation to both people and nature. The tangata whenua (people of the land) have a role as kaitiaki (guardians) to preserve the mauri, wāhi tapu (sacred sites) and natural taonga (treasures) in their area." http://www.environmentguide.org.nz/issues/biodiversity/maori-and-biodiversity/

These three frameworks are interwoven with the experiences we have in and outside of the classroom, and we learn to recognize and name them during our experiences.

\section{Two design student projects}

The first project involved a group of design students working with a local stream. Using a range of different social, cultural and environmental histories and perspectives students learned to see, hear and understand the stream as a living system with mauri (life force).

Öwheo Rising was a student project initiated by Caro McCaw and visiting artist and scholar, Nina Czegledy (Toronto/Budapest). Ōwheo Rising was a collaborative interdisciplinary project that took place at Otago Polytechnic, in Dunedin, New Zealand in early 2016 that drew together storytelling and creative practices between Otago Polytechnic's Schools of Art and Design. The project focused on stories surrounding the Ōwheo stream that makes its way through North Dunedin and the University and Polytechnic campuses to the harbor. The Ōwheo also known as the Water of Leith or Leith Stream was originally given its Māori name "The place of Wheo", for a local chief whose village stood close to the steam's mouth. (https://en.wikipedia.org/wiki/Water_of_Leith_(New_Zealand) Although surrounded by native bush and birds at its source, the lower reaches of the stream are now contained within concrete channels as a result of major flooding in the $19^{\text {th }}$ and early $20^{\text {th }}$ centuries.

The project's aim was to develop creative participatory site-specific projects that helped to share the histories of this stream. We drew upon initial storytelling incorporated into the interior design of the Polytechnic's main campus, Te Ara Honohono, referring to the many crossing pathways of the site, to consider the mauri (life force) of the former site of the Ōwheo stream. For local Māori, despite the straightening and renaming of the Ōwheo stream, the wairua (spirit) of the stream still runs through this landscape, although now written over with other uses.

The project began with workshops and a one-day symposium with a number of invited guests introducing different perspectives relevant to the Ōwheo stream. These positioned the stream as part of a broader system including social and environmental histories, site-specific practices and local Māori perspectives. A month of development work saw students (in small teams) produce and iterate prototypes for site-specific works that considered the stream as part of a broader system of values, people and histories. The project concluded with an exhibition and walking symposium, where student works were presented and discussed in situ.

Project outcomes ranged from paper boat races including the local kindergarten, to sound enhanced seating, a faux and futuristic real estate auction and Augmented Reality works giving 
visible form to prior histories of the stream. We worked with the Otago Polytechnic Kaitohutohu office to ensure accurate histories and local relevant protocols were followed. Through learning about stories surrounding the stream this project aimed to increase environmental and cultural literacies surrounding the sites of our everyday learning, and develop specific creative responses through a wide range of media and materials, to protoype stage.

We spent time throughout the project walking the length of the stream, and testing prototypes in situ. Getting to know the stream during our autumn term was one of our memorable shared experiences. The final walking symposium took most of a day as we visited the many sites students had selected and became part of the stream's stories.

The second project involved a pair of design students working with a local eco-sanctuary and a flock of endangered endemic parrots. Orokonui Ecosanctuary is located 25 minutes north of Dunedin (and Otago Polytechnic) and was the site of a senior design student projects in 2019. The Kākā project was developed by design students Katherine Woodfield and Georgia Ryan, collaborating with Information Technology student Nick Mulrooney.

This project focused on developing design solutions that would help to educate local communities about behaviour and best practice in regards to Orokonui's flock of native parrots, known as kākā. While the sanctuary is always safe for them, kākā will fly beyond the fence, particularly during the day, as they forage for food. It is important to educate people living in nearby towns, lifestyle properties and farms, about the specific behaviours of these inquisitive birds so that property owners can protect the birds from hazards and the kākā have a good chance of survival. Kākā are described as indicator species (Recio et al 2016). They are vulnerable to predation, especially while on their nests, but if kākā are safe, the environment is likely to be safe for many other species.

The Kākā Project involved a year of research and project design, and included weekly visits to the sanctuary, meeting regularly with sanctuary staff and taking walks in the forest. The students engaged in academic research, expert interviews and stakeholder testing. Slowly, over the year, their relationships grew stronger, with each other, with the sanctuary's neighbours and project stakeholders and with the Orokonui forest and birds.

"Through these regular meetings and discussions, we realised the research aims of our project were how to educate, encourage and empower local communities to help local kākā thrive. Our tool of choice as designers was through interactive multimedia storytelling.... Our hope was that through applying our storytelling and design skills we would create products that are innovative, engaging, fresh and effective." (Woodfield and Ryan, The Kākā project dissertation 2019, p7)

Through their research and design process Woodfield and Ryan also consulted with local Māori advisors and identified important connections. A Māori approach to these conservation issues (kaitiakitanga) provided a deeper understanding of connections between the land and the people who live upon it. "Our project needed to respect these connections, and it also needed to emphasise the importance of kākā, both as an indicator species and as a taonga (treasured) species." (Woodfield and Ryan, The Kāka project unpublished dissertation 2019, p34)

The two designers developed a choice-based game and website to help neighbours generate empathy towards their local ecologies. It helped people living in the 'halo' surrounding the sanctuary to recognize that their own actions and decisions could have unintended consequences. This game has since received regional council funding for full development and local release. 


\section{Reflections}

In both cases these projects required us (teachers and learners) to go outside, to engage in embodied on-site learning and to observe our place in these local ecosystems. We found that along with observing our environments, listening and reflecting on local places, birds, fish and animals could help us understand the potential risks and benefits, intended and unintended. It was a form of social relationships with each other and with our broader stakeholders that became imperative to the work of designing suitable responses. This included understanding and sharing understandings with local people, including indigenous Māori. This sharing formed relationships of trust.

In the case of the Öwheo stream project, students first spent time getting to know the stream, as well as researching through local libraries, and museums, often finding an expert who was able to support their research. Students acknowledged that local experts were often wary of how the students planned to use their knowledge, ensuring that the student project shared only accurate and relevant information in helpful ways. Students recognised that they did have some knowledge of te Ao Māori, but that focusing on a site helped them to contextualise that understanding. The time spent outside was enjoyable too, and a welcome break from a classroom or computer lab. Students struggled at first to identify strategies for sharing their stories. But spending time outdoors helped students to find opportunities that they would not have considered in the safety of the classroom. Paper prototypes and models, and returning often to the sites to better understand the system of users that passed through their sites, were integral to their processes. Their design outcomes - that aimed to share the storytelling aspects of the Ōwheo stream - reflected this embodied engagement through the development of physical prototypes. These ranged from the use of manual illustrations, seeds embedded in handmade paper, and the development of a public seat on the site of a former food exchange. Our final event - a walking symposium - brought us together to share storytelling but without the habitual use of screens.

In the case of the Kākā Project, our partners (the manager, lead ranger and educator at the sanctuary) were at first confused and perhaps suspicious about how these predominantly digitally-skilled students could support their goals in a very non-digital eco-sanctuary. It was through our regular weekly visits and walks in the forest that we gained the trust, of both the human caretakers, and the local birds. As we listened and learned the stories of particular places and birds we felt that we were only slowly becoming capable of sharing these stories. Over the year we became regular visitors, and learned the different trails and sites, including what weather conditions brought lizards out to bask, and where we were likely to see which birds. We always had questions and were eager to learn. We felt that as we became part of the community of that place, we were becoming transformed in the process. Only then could we become appropriate ambassadors for sharing practices with the sanctuarys' neighbours. Although we were given the information we needed during our first few visits, it was many months later that we understood the importance of trust and embodied relationships, that allowed us to share the story with confidence. Since the students' first prototypes, they have received public funding to develop the stories, and are now working with professional game narrative designers to develop a more nuanced interactive game, that helps players develop empathy in order to take action in their own back yards, understand themselves as kaitiaki (guardians) part of a bigger system including more-than-human neighbours.

Both projects required empathy including and beyond human-centered design. Students were compelled to listen and learn carefully, working with the needs of others, including the non-human, and recognize the effects of other perspectives, inter-connected in a system. 
Elements of te Ao Māori were understood in context, and given context by Ron Bull, Māori advisor. To work in this way it was necessary for students and teachers to leave the comfort of the classroom and engage directly with the natural environment, in relationship with the world around them.

These ideas are not new. The benefits of learning outside is understood by educators in early childhood sector through the 'Forest Kindergarten' movement. Turtle, Convery and Convery define Forest Schooling as a philosophy of education that "broadly follows a holistic approach to learning, and is normally carried out in a natural or wild place such as a forest and is child led." (2015, p. 2) And I am drawn to biologists who have merged their science languages with others to create useful metaphors for thinking and acting in ways that reconnect us to earthly others. Donna Haraway (who works with biology and feminisms) challenges us to question our separate wholeness as beings, drawing upon "co-habitation, co-evolution and cross-species sociality" (2003) in order to refocus on ourselves as always in dynamic, co-operative systems equally biological and social. Deleuze and Guattari's (2004) philosophical use of the rhizome is another conceptual framework drawn from biology - referring to the model of a plant-root system that grows through interconnection, so that its path of development can't be traced or separated. More recently Robin Wall Kimmerer brings her Native American worldview together with her understanding as a biologist, to help us see the "grammar of animacy" a language of learning to live with a world that is fully alive, and responsive to the movements of others, including ourselves.

In each instance these are efforts to help us understand ourselves in place as part of interwoven, interdependent, co-evolved systems, too complex to be managed by us. Rather we can learn and teach how to manage ourselves. Frameworks such as ecologies, systems thinking and our local indigenous worldviews are useful ways of understanding these complex systems, and - I believe - education that employs projects such as these might help us all become more conscious actors in the world, interwoven with our environment.

\section{Literature}

Abram, David. (1996) The Spell of the Sensuous: Perception and Language in a More-thanHuman World, Vintage Books, NY

Abram, David. (2012) On Being Human in a More-than-human World Humans and Nature, July 22, 2012 retrieved from www.humansandnature.org/to-be-human-david-abram

Abram, David (2019) 'The Commonwealth of Breath: Climate and Consciousness in Animistic Perspective', Public lecture, Reed College, Portland OR, April 172019

Allen, Will. (2021) Learning for sustainability, retrieved from https://learningforsustainability.net/systems-thinking/

Deleuze, G., \& Guattari, F. (2004). A thousand plateaus: Capitalism and schizophrenia. London: Continuum.

Environment Guide New Zealand, Environment Foundation (supported by NZ Law Foundation), Auckland New Zealand. Last updated 2018, retrieved 5 April 2021, from www.environmentguide.org.nz/issues/biodiversity/maori-and-biodiversity/

Golley, Frank, B. (1993) A History of the Ecosystem Concept in Ecology: More Than the Sum of the Parts. New Haven: Yale University Press, citing Arthur Tansley (1935). 
Galloway, Anne, Towards Fantastic Ethnography and Speculative Design September 17, 2013 Ethnography Matters http://ethnographymatters.net/blog/2013/09/17/towards-fantastic-ethnography-and-speculative-design/

Haraway, Donna (2003) The Companion Species Manifesto: Dogs, People, and Significant Otherness. United Kingdom: Prickly Paradigm Press.

Lister, Nina Marie. (1998) "A Systems Approach to Biodiversity Conservation Planning," Environmental Monitoring and Assessment 49 (2/3), pp 123-155

Reed, Chris and Lister, Nina-Marie (2014) Ecology and Design: Parallel Genealogies

Ecological thinking remains a powerful lens for understanding complex adaptive systems.

(April 2014) DOI: 10.22269/140414

Recio, Mariano, Payne, K. and Seddon, P. (2016) 'Emblematic forest dwellers reintroduced into cities: resource selection by translocated juvenile kaka' Current Zoology, Volume 62, Issue 1, February 2016, Pages 15-22, DOI: 10.1093/cz/zov010

Turtle, Christina, Convery, I. \& Convery, $\mathrm{K}$ in Yvonne Xian-han Huang (Reviewing Editor) (2015) Forest Schools and environmental attitudes: A case study of children aged 811 years, Cogent Education, 2:1, DOI: 10.1080/2331186X.2015.1100103

UNESCO Policy Brief: Advancing ESD Policy (2018) 'Education for Sustainability and the SDGs: Learning to Act, Learning to Achieve'. Retrieved from https://en.unesco.org/sites/default/files/gap_pn1_esd_and_the_sdgs_policy_brief_6_page_version.pdf 2 April 2021

Wall Kimmerer, Robin. (2017) 'Learning the Grammar of Animacy' Anthropology of Consciousness, Volume 28, Issue 2. Special Issue: Way Out Voices: A Phenomenology of Interbeing. Fall 2017: 27 September 2017. Pages 128-134 DOI: 10.1111/anoc.12081

Wikipedia entry: 'Water of Leith' retrieved 11 October 2020 https://en.wikipedia.org/wiki/Water_of_Leith_(New_Zealand)

Woodfield, Katherine and Ryan, Georgia. (2019) 'The Kākā Project', unpublished dissertation as partial fulfilment for BDes (Hons) at Otago Polytechnic. 